\title{
VISIT TO THE NATIONAL UNIVERSITY, SAN DIEGO, USA: 30 JULY 1999
}

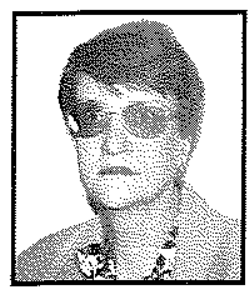

Dr VJ Ehlers

Dept. of Advanced Nursing Sciences

Unisa

\section{BACKGROUND INFORMATION}

During the International Council of Nurses (ICN) Centennial Conference in London (27 June till 1 July 1999), Dr Mary Hazzard, Professor in the Department of Nursing at the National University, San Diego extended an invitation to Dr Ehlers to visit the National University in San Diego during her planned study tour of California.

\section{HISTORICAL DEVELOPMENT}

The National University was founded in 1971 as an independent, non-profit institution of higher learning, focusing on the unique needs of midcareer adult learners, who are not seeking traditional residential university programmes. According to its information brochure, the National University is the third largest private university in California. More than 60000 students had completed their studies in the arts and sciences, business, education, human services, nursing and technology at the beginning of 1999.

\section{MISSION STATEMENT OF THE NATIONAL UNIVERSITY}

The National University's aims are reflected in its mission statement declaring that it is "dedicated to making lifelong learning opportunities accessible, challenging, and relevant to a diverse population of adult learners. Its aim is to facilitate educational access and academic excellence through innovative delivery systems and relevant programs that are learner-centered, successoriented, single-focused, and technologically responsive. National University's central purpose is to promote continuous learning by offering a diversity of instructional approaches; by encouraging scholarship; by engaging in collaborative community service, and by empowering its constituents to become responsible citizens in an interdependent, pluralistic, global community" (General Catalog, 1999:19).

\section{ORGANISATION OF THE NATIONAL UNIVERSITY}

The National University's headquarters are in San Diego, Southern California, but it has nine major regional centers in metropolitan areas throughout California and 22 learning centers near major freeways ensuring easy access from students' homes and offices.

The National University offers 47 graduate and undergraduate programmes and 17 teacher credential and certificate programmes. All these courses are accredited by the appropriate agencies, including the Western Association of Schools and Colleges (WASC) accrediting higher learning institutions in California, Hawaii and Guam. The Bachelor of Science degree in Nursing (BSN) has been accredited by the National League for Nursing Accrediting Commission (NLNAC), and has obtained preliminary approval by the Commission on Collegiate Nursing Education (CCNE). This University was ranked $51 \mathrm{st}$ nationally among 3600 institutions awarding master degrees to minorities.

Admission criteria to the National University meet California's admission requirements, but consider the candidates' previous academic records as well as their professional experience. Tuition fees are billed monthly, because courses are taught for one month at a time. The National University's unique one-course-per-month format enables adult learners to attend classes during evenings or on Saturdays (although certain programmes are available during the daytime). Classroom instruction is augmented by the University's server via Internet, e-mail, and the World Wide Web (www.online.nu.edu). The National University's online programmes include weekly audio and video lectures and discussion sessions with classmates participating in specific virtual classrooms. Online programmes include a Global MBA, the Bachelor of Arts in Global Studies, and the Bachelor of Science in Nursing, a Bachelor of 
Arts degree with a major in Media and Multimedia arts, and a Master's degree in Electronic Commerce.

Three major schools comprise the National University, namely the

- School of Education and Human Services (offering nursing courses amongst numerous others)

- School of Arts and Sciences

- School of Business and Administration (besides offering numerous business and management courses this school also offers courses in Health Care Administration, whilst Educational Administration is offered by the School of Education and Human

- Services - the reason for this apparent discrepancy could not be determined).

\section{NURSING COURSES OFFERED BY THE NATIONAL UNIVERSITY}

\section{Bachelor of Science in Nursing (BSN)}

The information brochure specifies that the aim of this course is to prepare registered nurses to assume greater professional responsibilities in the complex health care environment, by developing their critical thinking, communication and therapeutic nursing skills within the framework of transcultural nursing. A number of compulsory courses emphasise transcultural aspects such as Cultural Anthropology, Spanish in the Professional Workplace for English Speakers, Applications of Cross-Cultural Communication in the Workplace, Understanding Cross-Cultural Dynamics of Human Behavior, Understanding Cultural Pluralism in American Society, and Enhancing Learning in a Cross-Cultural Context. The BSN course allows for specialising in one of the following career options: Public Health Nursing, Community Nursing, Acute Care Nursing or Home Health Nursing. In addition to nursing sciences, the BSN candidates also need to complete general education requirements in the following four fields:

- Writing, Speech and Communication

- Natural Sciences, Mathematics and Computer Systems

- Humanities, Literature and Fine Arts

- Social and Behavioral Sciences.

\section{Master of Science in Nursing (MSN)}

The University's 1999 General Catalog specifies that the purpose of the MSN course is to prepare students to make the transition to the role of Advanced Practice Nursing as a Case Manager for a specified population. The abilities to practice both independently and collaboratively are stressed throughout this course.

In order to be admitted to the MSN course, candidates must be graduates of an NLN accredited BSN programme, hold current active licences to practice nursing in the State of California, and meet a number of other academic and personal criteria. The MSN programme includes courses in Quantitative and Qualitative Research, Cross-Cultural Dynamics of Human Behavior, Computer Applications, Linking Nursing Theory and Practice and Research. Actual research and clinical practicums are also required.

\section{BSN Programmes for Spanish Speaking Registered Nurses in South American Countries}

These courses were planned to be offered in Spanish by means of distance education. However, none of these courses could be implemented during 1999, because the Department of Education of California requires that tertiary education be offered in English and because the candidates from the South American countries could not meet the university admission criteria of California. Consequently, admission courses and English courses need to be designed specifically to enhance these potential students' qualifications prior to their admission to California's tertiary education system.

\section{CONCLUSION}

It was indeed a privilege to visit this private university which renders major inputs towards enhancing students' qualifications, including those of registered nurses. A number of Californians and members of staff of the National University need to be thanked for making this visit a reality, for freely providing information and for spending time with me. In conclusion, the words of the National University's President, Jerry C Lee, seem to summarise the activities and the future vision of this university: "... We are proud of our recent accomplishments... our continued movement toward ever higher levels of academic quality, our growing faculty and its accomplishments, and our responsive attitude 
toward students. We look forward to an even more distinguished future as we continue to seek new ways to meet the needs of our students, their future employers, and the communities which National University serves" (General Catalog, 1999:foreword).

\section{REFERENCES}

Information Brochure 1999: National University. San Diego.

General Catalog (vol. 61) 1999: National University. San Diego.

\section{USEFUL ADDRESSES}

Dr Mary E Hazzard, Professor of Nursing

E-mail:mhazzard@nu.edu

National University

11255 North Torrey Pines Road

LA JOLLA, San Diego, California, USA, CA 92037-1011

Fax: +(619) 642-8709

Internet: www.nu.edu 